http://dx.doi.org/10.11646/zootaxa.3652.4.7

http://zoobank.org/urn:lsid:zoobank.org:pub:46A474BE-A0DA-4632-B1B3-845D18859FFA

\title{
The identity of the enigmatic genus Stenocolletes Schrottky (Hymenoptera: Tiphiidae)
}

\author{
MARIANO LUCIA ${ }^{1}$, LEOPOLDO J. ALVAREZ1, VICTOR H. GONZALEZ ${ }^{2,3}$ \\ \& ALBERTO H. ABRAHAMOVICH ${ }^{1}$ \\ ${ }^{1}$ División Entomología, Museo de La Plata, Universidad Nacional de La Plata, Paseo del Bosque s/n, 1900FWA, La Plata, Argentina. \\ CONICET.E-mail: mlucia@fcnym.unlp.edu.ar,lalvarez@fcnym.unlp.edu.ar,albertoa@fcnym.unlp.edu.ar \\ ${ }^{2}$ Southwestern Oklahoma State University, Biological Sciences, 100 Campus Drive, Weatherford, Oklahoma, 73096, USA. \\ E-mail: victorgonzab@gmail.com \\ ${ }^{3}$ Division of Entomology, Natural History Museum, and Department of Ecology \& Evolutionary Biology, 1501 Crestline Drive - Suite \\ 140, University of Kansas, Lawrence, Kansas, 66045, USA
}

\begin{abstract}
The identity of Stenocolletes Schrottky and its single species, Stenocolletes pictus Schrottky, has remained a mystery since their description in 1909. Stenocolletes was originally placed in the bee family Colletidae but no known American colletid matches the original description. The type of S. pictus is likely lost as are large portions of Schrottky's collection. Herein, we describe and designate as neotype a historic specimen that closely matches Schrottky's description and place it in the current classification. Stenocolletes pictus is conspecific with the South American thiipid wasp Calchaquila albinervis (Brèthes, 1913). Both generic and specific names are new synonymous of Stenocolletes and pictus, respectively (new junior synonym). Stenocolletes pictus is also recorded for the first time from Córdoba, Argentina.
\end{abstract}

Key words: Anthoboscidae, Anthophila, Argentina, Colletidae, Panurginae, Tiphiidae

\section{Introduction}

Among the nearly 600 species of insects described by Curt Schrottky (1874-1937), the identity of the genus Stenocolletes Schrottky and its single species, Stenocolletes pictus Schrottky, 1909, have remained a mystery. Schrottky (1909) described Stenocolletes from two males collected by Carlos Bruch (1869-1943) in Catamarca, Argentina, and as indicated by its generic name, he placed it in the short-tongue bee family Colletidae. Although Schrottky did not examine the tongue of his specimens to avoid further damage (Schrottky indicated that the box with the type specimens arrived broken), he regarded Stenocolletes as the most distinctive of the hairy Colletidae, particularly because of the yellow maculation on all tagmata (Schrottky 1913). That taxonomic placement was not questioned by subsequent authors (Ducke 1912; Sandhouse 1943; Michener 1965, 1989) until Michener (2000, 2007) doubted that Schrottky's Stenocolletes was actually a colletid given that its body coloration is not found in any other American colletid bee. He suggested that Stenocolletes might instead be a panurgine bee of the genus Psaenythia Gerstaecker.

The identity of Stenocolletes could be easily clarified by examining the type of Stenocolletes pictus. However, it is well-known among entomologists that a large portion of Schrottky's private collection was destroyed and that the remaining part is scattered among multiple institutions in South America, United States and Europe (Rasmussen et al. 2009). Thus, as of today, the existence or whereabouts of the type of S. pictus is unknown and the taxonomic placement of the species remains questionable.

As a part of an ongoing study of the Argentinean melittofauna, we found in the Alejandro Ogloblin collection at the Museo de la Plata, Argentina (MLP), a male specimen (Figs 1-4) labeled "Stenocolletes pictus Schrottky, Plesiotipus" [Plesiotype]. The specimen agrees closely with the original description by Schrottky in the body pubescence, size, and color. However, it was collected in the providence of Córdoba in 1942, several years after 